Stanisław Goźdź-Roszkowski

Katedra Języków Specjalistycznych

oraz Komunikacji Międzykulturowej

Uniwersytet Łódzki

stanislaw.gozdz@uni.lodz.pl

\title{
WYMIAR GATUNKOWY ZDANIA ODRĘBNEGO I JEGO UZASADNIENIA NA PRZYKEADZIE ORZECZEŃ TRYBUNAEU KONSTYTUCYJNEGO W POLSCE. ZARYS PROBLEMATYKI
}

Zdanie odrębne i jego uzasadnienie to jedno z najbardziej intrygujących, a jednocześnie najmniej zbadanych elementów wypowiedzi sędziów. $Z$ jednej strony zdanie odrębne, zwane również votum separatum czy contravotum, nie ma wartości precedensowej i nie rodzi skutków prawnych mających bezpośredni wpływ na wynik postępowania sądowego. Z drugiej strony możliwość wyrażenia sprzeciwu przez pojedynczego sędziego uważana jest za niezwykle istotny aspekt procesu uzasadnienia decyzji stosowania prawa. Instytucja zdania odrębnego jest często spotykana w praktyce sądowej ${ }^{1}$. Dotyczy to zarówno prawa kontynentalnego, jak i tradycji anglosaskiej, choć pełni ona tam nieco inne funkcje i może przybierać odmienne formy (Kirby 2007). W Polsce zdanie odrębne jest dopuszczane w zasadzie we wszystkich postępowaniach przed sądami powszechnymi, choć jego stopień uregulowania jest dość zróżnicowany (Grochowski 2015). Fragmentaryczność regulacji prawnej widoczna jest szczególnie w obszarze sposobu uzasadnienia zdań odrębnych. Konstrukcja uzasadnienia zdań odrębnych pozostawiona została w znacznej mierze praktyce sądowej. Jednocześnie wraz z coraz większą dostępnością tekstów orzeczeń sądowych w Internecie poszerza się krąg ich odbiorców i rośnie

${ }^{1}$ Warto jednak pamiętać, że votum separatum nie jest w pełni akceptowane w niektórych krajach europejskich, takich jak Austria, Belgia, Francja czy Włochy, gdzie zdanie odrębne nie jest publikowane. Zdania odrębne nie są też dozwolone w Trybunale Sprawiedliwości (Derlatka 2018: 647). 
społeczne znaczenie uzasadnień sądowych, w tym uzasadnień zdań odrębnych. Grochowski (2015: 138) wskazuje na to, iż zdanie odrębne „wyszło z cienia”, dowodząc, iż obecnie otwarcie mówi się, że wyrok zapadł niejednomyślnie, ale i jego uzasadnienie nie jest już traktowane jako rzecz wymagająca ukrycia przed szerszym gronem odbiorców, czy też jako wewnętrzna sprawa sądu (Lis-Staranowicz 2015).

O ile w literaturze prawniczej instytucja zdania odrębnego budzi ostatnio spore zainteresowanie, o tyle z perspektywy lingwistycznej stanowi zupełnie nowy obiekt badań. Niniejszy artykuł ma na celu zasygnalizowanie potrzeby bardziej systematycznego i wieloaspektowego oglądu votum separatum i jego uzasadnienia, które powinno przede wszystkim skoncentrować się na wymiarze gatunkowym poprzez zwrócenie uwagi na status wzorca gatunkowego, zakresy jego wariantywności oraz sposoby funkcjonowania różnych jego aspektów (zob. Wojtak, Malinowska 2015). Wybór orzecznictwa Trybunału Konstytucyjnego (TK) nie jest przypadkowy, lecz odzwierciedla zwiększone zainteresowanie, jakie można zauważyć w literaturze prawniczej (zob. Grochowski 2015; Derlatka 2018) oraz w środkach masowego przekazu w związku z trwającym kryzysem konstytucyjnym w Polsce (np. Bachryj-Krzywaźnia 2017; Goźdź-Roszkowski, Kopytowska 2019).

\section{Zdanie odrębne i jego uzasadnienie: pojęcie, funkcje i adresaci}

Pojęcie zdania odrębnego wydaje się raczej zrozumiałe i oczywiste. Najogólniej rzecz ujmując, zdanie odrębne w kontekście sądowym to wypowiedź sędziego odmienna od stanowiska większości sędziów określonego składu orzekającego. W warunkach polskiego systemu prawnego wiąże się w oczywisty sposób z orzekaniem w składach kolegialnych, w których doszło do wyodrębnienia się dwóch stanowisk: większościowego i mniejszościowego. Dopuszczalność zgłoszenia sprzeciwu wobec orzeczenia większości sędziów zawsze budziła kontrowersje i niejednoznaczne opinie. W polskiej literaturze prawniczej najczęściej wskazywano na ryzyko osłabienia czytelności i wyrazistości uzasadnienia orzeczenia, argumentując, iż ujawnienie różnicy zdań w składzie osłabia „moc” orzeczenia i budzi wątpliwości co do słuszności orzeczenia. Istotną rolę odgrywa legitymizacja społeczna podjętej decyzji, która - jak twierdzono - może zostać osłabiona (Grochowski 2015). Wydaje się, że wyrok, wobec którego zgłoszono kilka zdań odrębnych posiada w odbiorze społecznym słabszą legitymizację niż wyrok, który zapadł jednomyślnie (Derlatka 2018). Warto $\mathrm{w}$ tym miejscu zasygnalizować odmienne podejście do roli uzasadnień zdania odrębnego w kulturze prawnej anglo-amerykańskiej, gdzie tradycyjną praktyką 
stosowaną przez sędziów jest formułowanie oddzielnych opinii w danej sprawie (tzw. seriatim opinions). Znacznie większa niż w prawie kontynentalnym rola uzasadnień zdań odrębnych związana jest ze specyfiką prawa precedensowego (Zych 2017)2.

Nie wchodząc w polemikę dotyczą zalet i wad instytucji zdania odrębnego, wypada zauważyć, iż jego zasadniczą cechą jest dialogiczność. W przeciwieństwie do uzasadnienia decyzji większości, w tym przypadku mamy do czynienia z indywidualną wypowiedzią sędziego, która poddaje krytycznemu osądowi sentencję orzeczenia i/lub jego motywy. Wydaje się, że w refleksji językoznawczej nad zdaniem odrębnym oraz jego uzasadnieniem należy uwzględnić perspektywę komunikacyjną. Jest to swoista wypowiedź docierająca do różnych odbiorców. Jej zasięg i krąg adresatów będą oczywiście zależeć od wagi rozstrzygnięcia czy też pozycji sądu rozpoznającego daną sprawę. Poza podstawowymi adresatami, a więc pozostałymi członkami składu orzekającego oraz stronami postępowania, odbiorcami mogą być również sędziowie sądów niższej instancji rozpatrujący podobne kwestie, prawnicy teoretycy czy dziennikarze (w przypadku spraw wzbudzających zainteresowanie opinii publicznej). Wzrastające znaczenie odrębnego stanowiska sędziego można także upatrywać w rosnącej liczbie zdań odrębnych. W roku 2016 w TK zgłoszono 90 zdań odrębnych w porównaniu do 47 w 2015 czy 42 w 2014. Rosnąca liczba zdań odrębnych to niewątpliwie pokłosie trwającego w Polsce kryzysu konstytucyjnego, a zdania odrębne trudno uznać za politycznie neutralne (Derlatka 2018). Może to świadczyć o rosnącej wśród sędziów świadomości dotyczącej zasięgu społecznego i siły oddziaływania ich wypowiedzi.

\section{Zdanie odrębne i jego uzasadnienie: forma i struktura}

Regulację pozwalającą sędziemu sądu konstytucyjnego na przedstawienie swego odrębnego stanowiska przyjęto w ustawie o TK z 1 sierpnia 1997 roku i utrzymano w ustawie z 25 czerwca 2015 roku o TK oraz w ustawie z 22 lipca 2016 roku. W przypadku orzeczeń TK stanowisko takie może przybrać formę ustną oraz pisemną. Ustawa o TK nakłada na sędziów obowiązek sporządzenia uzasadnienia na piśmie w ciągu miesiąca od wydania orzeczenia (Królikowski 2015). Jak zasygnalizowano wyżej, uwaga ustawodawcy koncentruje się na

${ }^{2}$ Wyczerpujące porównanie instytucji zdania odrębnego w tradycjach prawa anglosaskiego i kontynentalnego zainteresowany Czytelnik znajdzie u Kirby’ego (2007). Keleman (2017) omawia tę problematykę na przykładzie europejskich sądów konstytucyjnych. 
sposobie wyrażania zdania odrębnego, a nie na jego uzasadnieniu. Grochowski podkreśla, że zdanie odrębne i jego uzasadnienie są „aktami odrębnymi konstrukcyjnie" ponieważ złożenie votum separatum zawsze poprzedza przedstawienie jego motywów (2015: 143). W art. $114 \$ 1$ Kodeksu Postępowania Karnego ustawodawca wymaga, aby sędzia w zdaniu odrębnym wskazał, „w jakiej części i w jakim kierunku kwestionuje orzeczenie”. Powoduje to, iż można spodziewać się, iż zdanie odrębne oraz jego uzasadnienie będą różnić się znacznie pod względem stopnia formuliczności, tzn. stopnia wykorzystania gotowych schematów zdaniowych mających charakter czysto funkcjonalny. Zanim przyjrzymy się blizzej zarówno elementom zdania odrębnego, jak i jego uzasadnieniu, warto umieścić tę wypowiedź sędziego w kontekście ram strukturalnych wyroku TK i jego uzasadnienia (rysunek 1).

Sentencja:

Komparycja/ rubrum

Tenor: rozstrzygnięcie „orzeka” / „ponadto postanawia”

Uzasadnienie

Część I: historyczna

Część II: „na rozprawie”

Część III: uzasadnienie prawne (część merytoryczna)

Zdanie (lub zdania) odrębne

Rysunek 1. Struktura wyroku TK

Źródło: Goźdź-Roszkowski 2020a.

Przedstawiona struktura wyroku TK ukazuje wzorzec normatywny $\mathrm{w}$ sensie prawnym czy też instytucjonalnym (zob. Wojtak $2004 \mathrm{w}$ odniesieniu do uzasadnień decyzji administracyjnej). Co ciekawe, wzorzec ten rozciąga się również na uzasadnienie sentencji wyroku, rodząc pytanie o stopień jego skonwencjonalizowania oraz relację między podziałem wynikającym $\mathrm{z}$ narzuconej struktury prawnej a podziałem wyłonionym dzięki analizie językoznawczej, zwłaszcza dotyczącej badania mającego na celu identyfikację segmentów tekstu o określonej funkcji dyskursywnej w wyniku tzw. move 
analysis (Swales 1990; Bhatia 1993)33. Poza zróżnicowaniem wewnętrznym - w obrębie poszczególnych części czy też segmentów uzasadnienia do sentencji - niezwykle istotne zagadnienie to relacja uzasadnienia votum separatum w odniesieniu do uzasadnienia orzeczenia, za którym opowiedziała się większość składu sędziowskiego. Jak zasygnalizowano wyżej, uzasadnienie votum separatum jest $\mathrm{z}$ założenia wypowiedzią o charakterze dyskursywnym i wysoce dialogicznym, gdyż zasadza się na polemice z sentencją orzeczenia oraz argumentacją zawartą w jego motywach. Grochowski (2015) słusznie postrzega dyskursywność jako klucz do zrozumienia jej roli w komunikacji $\mathrm{z}$ różnymi kategoriami odbiorców.

Analiza korpusu tekstów liczącego 121866 wyrazów i składającego się z 45 zdań odrębnych pobranych z internetowej bazy orzeczeń $\mathrm{TK}^{4}$ ujawnia, iż sędzia jest niejako zobowiązany do użycia określonych, powtarzalnych formuł językowych w celu zgłoszenia swojego sprzeciwu do orzeczenia większości, natomiast ma znacznie większą swobodę doboru środków językowych, określając motywy swojej decyzji. Poniższy przykład ilustruje sposób wyrażania zdania odrębnego do wyroku TK:

(1) Zdanie odrębne sędziego TK Stanisława Rymara do wyroku Trybunału Konstytucyjnego.

Na podstawie art. 68 ust. 3 ustawy z dnia 1 sierpnia 1997 r. o Trybunale Konstytucyjnym (Dz.U. Nr 102, poz. 643, ze zm.) zgłaszam zdanie odrębne do wyroku Trybunału Konstytucyjnego z 19 grudnia 2012 r. o sygn. K 9/12.

W przykładzie (1) widać, iż wskazanie zakresu zdania odrębnego pojawia się $\mathrm{w}$ nagłówku tekstu, a następnie jest powtórzone $\mathrm{w}$ treści votum separatum. Zgłoszeniu zdania odrębnego towarzyszy niezmiennie odwołanie do jego podstawy prawnej oraz podanie daty oraz sygnatury sprawy, której dotyczy wyrok. Analogicznie tworzone jest zdanie odrębne do uzasadnienia wyroku:

(2) Zdanie odrębne sędziego TK Marka Zubika do uzasadnienia wyroku Trybunału Konstytucyjnego z dnia 28 czerwca 2016 r. o sygn. SK 31/14

Na podstawie art. 99 ust. 2 zdanie drugie ustawy z dnia 25 czerwca $2016 \mathrm{r}$. o Trybunale Konstytucyjnym (Dz.U. z 2016 r. poz. 293) zgłaszam zdanie odrębne do uzasadnienia wyroku z 28 czerwca 2016 r. o sygn. SK 31/14.

Zasada dowolności w wyborze kwestii, co do której sędziowie mogą zgłosić swój sprzeciw widoczna jest w bardzo precyzyjnym wskazaniu zakresu zdania

3 Próbę takiej analizy można znaleźć w Goźdź-Roszkowski 2020 b.

4 Zob. https://ipo.trybunal.gov.pl/ipo (dostęp: 26.07.2020). 
odrębnego, które może odnosić się do sentencji, do uzasadnienia wyroku (przykład 3), jak również jedynie do określonego fragmentu wyroku (przykład 4):

(3) Nie zgadzam się z sentencją oraz uzasadnieniem wyroku.

(4) Na podstawie art. 68 ust. 3 ustawy z dnia 1 sierpnia 1997 r. o Trybunale Konstytucyjnym (Dz.U. Nr 102, poz. 643, ze zm.; dalej: ustawa o TK) zgłaszam zdanie odrębne do punktu 1 lit. a części I wyroku Trybunału Konstytucyjnego z dnia 7 listopada $2013 \mathrm{r}$. w sprawie o sygn. K 31/12.

Powyższe przykłady pokazują, iż sposób sygnalizowania zdania odrębnego jest wysoce sformalizowany i skonwencjonalizowany, a sędziowie posługują się gotowymi schematami zdaniowymi. Ich treść odzwierciedla wspomniany wyżej wymóg ustawodawcy dotyczący precyzyjnego określenia kierunku zakresu, w jakim orzeczenie podlega zakwestionowaniu. Jest to istotne, gdyż cechą wspólną zdań odrębnych jest szeroki zakres kwestii, do jakich mogą się odnieść. Podobnie jak w tradycji anglosaskiej, odrębne stanowisko sędziego dotyczy jednak zazwyczaj sentencji orzeczenia i/lub jego uzasadnienia ${ }^{5}$. Wyrażenie sprzeciwu oraz wskazanie jego zakresu to elementy votum separatum charakteryzujące się wysokim stopniem formuliczności. Natomiast, jak wspomniano, sposób uzasadnienia zależy od wielu czynników w znacznej mierze subiektywnych. Analiza treści uzasadnień sugeruje występowanie pewnych powtarzalnych, choć nieidentycznych form dyskursywnych. Jedną z charakterystycznych form jest wskazanie zakresu, w którym sędzia zgadza się ze stanowiskiem większości, zanim przystąpi do sprecyzowania obszaru, z którym się nie zgadza. Ilustruje to przykład 5 (wyróżnienie w tekście - SGR).

(5) Pragnę podkreślić, że podzielam pogląd Trybunału Konstytucyjnego o zasadności istnienia obowiązku właściciela lub posiadacza pojazdu wskazania, komu powierzyl pojazd do kierowania w oznaczonym czasie $[\ldots]$

Przychylam się także do stanowiska Trybunału Konstytucyjnego, że konieczne jest zdecydowane oddzielenie postępowania w sprawie popelnienia wykroczenia $\mathrm{z}$ art. $92 \mathrm{a}$ k.w., od postępowania w sprawie popełnienia wykroczenia $\mathrm{z}$ art. $96 \$ 3$ k.w.

Po wskazaniu zakresu konsensusu w odniesieniu do określonego orzeczenia następuje zazwyczaj wyraźne zasygnalizowanie kwestii spornej:

${ }^{5} \mathrm{~W}$ tradycji common law podział ten odpowiada dwóm rodzajom odrębnego stanowiska sędziego: dissenting opinion oraz concurring opinion. 
(6) Orzekając, że w procesie tworzenia ustawy z dnia 18 sierpnia 2011 r. o zmianie ustawy - Prawo o ustroju sądów powszechnych oraz niektórych innych ustaw (Dz.U. Nr 203, poz. 1192; dalej: ustawa zmieniająca) nie doszło do naruszenia trybu ustawodawczego, a zatem - inaczej niż utrzymywał wnioskodawca - nie doszło do naruszenia art. 2 w związku z art. $7 \mathrm{i}$ art. 119 ust. 1 Konstytucji, Trybunat Konstytucyjny opart się na dwóch tezach, z którymi się nie zgadzam.

Wskazanie kwestii spornych umiejscowione jest zwykle tuż po wyrażeniu votum separatum, uszczególawiając sygnalizowany w samym votum separatum zakres kwestionowania orzeczenia. Stanowi tym samym element czytelnie sygnalizujący rozpoczęcie etapu uzasadnienia. Przykłady 7-10 pokazują kilka możliwych realizacji tego elementu uzasadnień:

(7) Zdanie odrębne uzasadniam następująco.

(8) Obowiązek zgłoszenia zdania odrębnego motywuję następująco.

(9) Nie zgadzam się z rozstrzygnięciem Trybunału z następujących powodów.

(10) Nie mogę podzielić tego orzeczenia ani jego uzasadnienia, i to $\mathrm{z}$ wielu powodów. Najważniejsze przytaczam poniżej.

Przykłady te wskazują na znaczny stopień wariantywności w obrębie wykorzystywanych przez sędziów formul językowych. W zasadzie jeszcze tylko w samym zakończeniu uzasadnienia widać podobny, stosunkowo wysoki stopień formuliczności.

(11) $\mathrm{Z}$ tych przyczyn zdecydowałem się na zgłoszenie zdania odrębnego.

(12) Z powyższych względów złożyłam zdanie odrębne.

(13) $\mathrm{Z}$ powyższych względów zgłosiłem niniejsze zdanie odrębne.

Przykłady 11-13 nie różnią się znacząco od siebie. Ich cechą charakterystyczną jest wskazywanie przez sędziego na motywy zgłoszenia votum separatum. Co ciekawe, w wielu wypowiedziach można dostrzec aspekt obligatoryjny zgłoszenia votum separatum postrzegany w kategoriach aksjologicznych jako moralny obowiązek sędziego, który z ważnych powodów nie może zgodzić się z decyzją większości składu orzekającego.

(14) $\mathrm{Z}$ podanych wyżej względów czułem się zobligowany do zgłoszenia zdania odrębnego do wyroku Trybunału Konstytucyjnego.

(15) Mając na uwadze wszystkie powyższe argumenty, złożenie zdania odrębnego w niniejszej sprawie uznatem za konieczne. 


\section{Zakończenie. Podstawowe kierunki badawcze nad zdaniem odrębnym i jego uzasadnieniem}

Biorąc pod uwagę znikomy zakres refleksji juryslingwistycznej nad zdaniem odrębnym i jego uzasadnieniem, warto naszkicować zasadnicze kierunki, w jakich można prowadzić dalsze badania. Przede wszystkim ustalenia wymaga określenie wymiaru gatunkowego (genologicznego) tego typu wypowiedzi sędziowskiej. Czy votum separatum i jego uzasadnienie stanowi osobny gatunek dyskursu sędziowskiego, czy też przynależy do kategorii orzeczeń sądowych i ich uzasadnień? Czy podlega procesom standaryzacji na poziomie gatunkowego schematu (trwałość komponentów, ich następstwo, formuliczność)? Zagadnienie to dotyczy zwłaszcza uzasadnienia w kontekście niemal nieograniczonej swobody sędziów w konstruowaniu jego treści. Dalsze pytania mogą koncentrować się na statusie wzorca gatunkowego oraz zakresów jego wariantywności. Podobnie $\mathrm{w}$ wymiarze tekstologicznym zagadnienia badawcze powinny ogniskować się wokół problematyki organizacji tekstowej komunikatu, ramy tekstowej czy wewnętrznej spójność (koherencji), prowadząc do kluczowego pytania o autonomiczność votum separatum i jego uzasadnienia jako samodzielnej jednostki tekstowej.

Osobnym zagadnieniem jest aspekt wartościowania oraz negocjowania postaw nieodłącznie związany z argumentacją sędziowską (np. Goźdź-Roszkowski 2017; Pontrandolfo, Goźdź-Roszkowski 2014). Dyskurs sądowy pozostaje tutaj obszarem stosunkowo mało zbadanym. W kontekście uzasadnień zdań odrębnych ocenie podlega przede wszystkim argumentacja zawarta w uzasadnieniu orzeczenia sądu. Analiza lingwistyczna może się łączyć z wieloma istotnymi pytaniami, np.:

- jak konstruowane jest wartościujące stanowisko sędziego i jaka jest rola wyrażeń wartościujących w uzasadnieniach decyzji stosowania prawa?

- czy sędziowie dokonując ocen posługują się schematycznymi i powtarzalnymi wyrażeniami?

- w jaki sposób dochodzi w tekście do prozodycznego rezonansu dokonanych wyborów semantycznych?

- jakie są strategie dystansowania się sędziów względem ocenianego obiektu (np. argumentacji stron postępowania, argumentów innych sędziów itd.) oraz jak kształtowane są relacje w stosunku do innych uczestników interakcji?

- czy sposoby wartościowania różnią się w zależności od języka, systemu i kultury prawnej, typu uzasadnienia?

Ostatnie pytanie może stanowić inspirację do podjęcia bardzo potrzebnych badań o charakterze porównawczym. Uwidacznia się również możliwość włączenia aspektu argumentacyjnego poprzez analizę języka odnoszącego się do 
zasad, wartości i metod wykładni stosowanych w uzasadnieniach. Taka perspektywa rodzi kolejne pytania, np. o istnienie wzorca argumentacyjnego polegającego na powiązaniu ze sobą kilku zasad, kilku wartości czy różnych metod wykładni.

Nie ulega wątpliwości, że zdanie odrębne wraz z uzasadnieniem stanowi nowy i obiecujący przedmiot badań włączających się w szeroki nurt analizy dyskursu instytucjonalnego. To szczególna forma wypowiedzi sędziowskiej wymagającej podejścia interdyscyplinarnego i połączenia różnych perspektyw metodologicznych ${ }^{6}$.

\section{Bibliografia}

Bachryj-Krzywaźnia M. (2017), W stronę despotii czy normalności? Medialne narracje wokót sporu o Trybunat Konstytucyjny, [w: ] J. Golinowski, S. Sadowski (red.), Pomiędzy mythos a logos społecznej zmiany, Bydgoszcz, s. 174-194.

Bhatia V.K. (1993), Analyzing Genre - Language Use in Professional Settings, London.

Derlatka M. (2018), Zdania odrębne w orzecznictwie Trybunatu Konstytucyjnego, [w:] M. Aleksandrowicz, M. Andruszkiewicz, A. Breczko, S. Oliwniak (red.), Demokracja, teoria prawa, sadownictwo konstytucyjne, Białystok, s. 647-658.

Garlicki L. (2010), Zdania odrębne w Europejskim Trybunale Praw Człowieka, [w: ] D. Dudek, M. Gapski, W. Łączkowski (red.), Amicus Hominis et Defensor Iustitiae. Przyjaciel Człowieka i Obrońca Sprawiedliwości. Księga Jubileuszowa w 70 rocznicę urodzin sędziego Ferdynanda Rymarza, Lublin.

Goźdź-Roszkowski S. (2017), Signaling sites of contention in judicial discourse. An exploratory corpus-based analysis of selected stance nouns in US Supreme Court opinions and Poland's Constitutional Tribunal judgments, „Comparative Legilinguistics. International Journal for Legal Communication”, t. 32, s. 91-117.

Goźdź-Roszkowski S. (2020a), Communicating dissent in judicial opinions: a comparative, genre-based analysis, „International Journal for the Semiotics of Law", t. 33(2), s. 381-401.

Goźdź-Roszkowski S. (2020b), Move analysis of legal justifications in Constitutional Tribunal judgments in Poland: What they share and what they do not,

${ }^{6}$ Niniejszy rozdział powstał $\mathrm{w}$ wyniku realizacji projektu badawczego o nr UMO-2018/31/B/HS2/03093 finansowanego ze środków Narodowego Centrum Nauki. 
„International Journal for the Semiotics of Law”, https://doi.org/10.1007/ s11196-020-09700-1 (dostęp: 26.07.2020).

Goźdź-Roszkowski S., Kopytowska M. (2019), Courts, constitutionality and conflicts in media representations. A case study in Polish rule of law crisis, [w:] F. Vogel (red.), Legal Linguistics Beyond Borders: Language and Law in a World of Media, Globalisation and Social Conflicts, Berlin, s. 339-362.

Grochowski M. (2014), Uzasadnienie zdania odrębnego, [w:] I. Rzucidło-Grochowska, M. Grochowski (red.), Uzasadnienia decyzji stosowania prawa, Warszawa, s. 138-169.

Kelemen K. (2017), Judicial Dissent in European Constitutional Courts: A Comparative and Legal Perspective, London-New York.

Kirby M. (2007), Judicial dissent. Common law and civil law traditions, „Law Quaterly Review", t. 123(3), s. 379-400.

Królikowski J. (2015), Uzasadnienia orzeczeń Trybunatu Konstytucyjnego, [w:] I. Rzucidło-Grochowska, M. Grochowski (red.), Uzasadnienia decyzji stosowania prawa, Warszawa, s. 427-439.

Lis-Staranowicz D. (2015), O wartości i potrzebie zdań odrębnych od wyroków Trybunatu Konstytucyjnego, [w:] P. Mikuli, A. Kulig, J. Karp (red.), Ustroje, tradycje i porównania. Ksiegga jubileuszowa dedykowana prof. dr hab. Marianowi Grzybowskiemu, Warszawa.

Pontrandolfo G., Goźdź-Roszkowski S. (2014), Exploring the local grammar of evaluation: the case of adjectival patterns in American and Italian judicial discourse, „Research in Language”, t. 12(1), s. 71-92.

Swales J. (1990), Genre Analysis: English in Academic and Research Settings, Cambridge.

Wojtak M., Malinowska E. (2015), Uzasadnienie decyzji administracyjnej w analizie lingwistycznej, [w:] I. Rzucidło-Grochowska, M. Grochowski (red.), Uzasadnienia decyzji stosowania prawa, Warszawa, s. 440-453.

Zych T. (2017), W poszukiwaniu pewności prawa. Precedens a przewidywalność orzeczeń sądowych $w$ tradycji prawa anglosaskiego, Toruń. 
Stanisław Goźdź-Roszkowski

\title{
A GENRE-BASED VIEW ON SEPARATE OPINION AND ITS JUSTIFICATION. AN EXPLORATORY STUDY OF THE CONSTITUTIONAL TRIBUNAL OPINIONS
}

\begin{abstract}
(Summary)
Surprisingly, there has been very little research into separate opinions in the legal linguistics literature. Very scarce attention has been paid to the linguistic and communicative aspects of how judges frame their disagreement. This chapter is one of the first attempts to examine the institution of votum separatum or separate opinion in the institutional context of Poland's Constitutional Tribunal. It starts with an overview of the concept, its functions and the range of recipients. This is then followed by an examination of its form and structure. The study demonstrates how judges tend to employ highly formulaic expressions to signal their disagreement despite the absence of clear guidelines that would prescribe ways in which their stance should be communicated. In addition, the analysis shows that declaring votum separatum and providing its justification are two different acts, not only legally but also linguistically, especially in terms of their formulaicity. Finally, directions for future research are outlined.
\end{abstract}

Key words: judicial discourse, separate opinion, legal communication, genre analysis 